\title{
Pollen morphology and study of the visitors (Hymenoptera, Apidae) of Solanum stramoniifolium Jacq. (Solanaceae) in Central Amazon
}

\author{
Alexandre Coletto da Silva ${ }^{1}$, Valdely Ferreira Kinupp², Maria Lucia Absy ${ }^{1}$ and Warwick Estevam Kerr ${ }^{3}$
}

Received: August 15, 2003. Accepted: February 19, 2004

\begin{abstract}
RESUMO - (Morfologia polínica e estudo dos visitantes (Hymenoptera, Apidae) de Solanum stramoniifolium Jacq. (Solanaceae) na Amazônia Central). A família Solanaceae tem ampla distribuição, principalmente nas áreas tropicais e subtropicais da América do Sul. Solanum L. é um dos mais importantes gêneros desta família com aproximadamente 1.200 espécies. O objetivo deste trabalho foi o de estudar a biologia floral com enfoque na morfologia polínica e no registro de algumas abelhas visitantes de S. stramoniifolium. Dados preliminares indicam a presença de uma espécie de abelha com ferrão e quatro espécies sem ferrão como visitantes de S. stramoniifolium. O pólen de $S$. stramoniifolium é tricolporado e psilado, ou seja, sem ornamentação. Conclui-se, após o estudo da biologia floral, que S. stramoniifolium constitui fonte potencial de pólen para diferentes espécies de abelhas com e sem ferrão, representando interessante campo para estudos de germinação, interações inseto-planta e biologia floral.
\end{abstract}

Palavras-chave: Solanum stramoniifolium, abelhas, pólen, polinização, acetólise

\begin{abstract}
Pollen morphology and study of the visitors (Hymenoptera, Apidae) of Solanum stramoniifolium Jacq. (Solanaceae) in Central Amazon). The Solanaceae family has a wide distribution, mainly in the tropical and subtropical areas of South America. Solanum L. is one of the most important genera of the family with approximately 1,200 species. The objective of this work was to study the floral biology, pollen morphology as well as to investigate the bee visitors of S. stramoniifolium. Preliminary data indicate the presence of one species of stinging bee and four species of stingless bees as visitors to $S$. stramoniifolium. The pollen of S. stramoniifolium is tricolporate and psilate or without ornamentation. In a word, S. stramoniifolium constitutes a potential source of pollen for different species of bees with and without sting, providing an interesting field for germination studies, insect-plant interactions and floral biology that are already under way.
\end{abstract}

Key words: Solanum stramoniifolium, bees, pollen, pollination, acetolysis

\section{Introduction}

The Solanaceae family comprises about 90 genera and 3,000 species with a wide distribution, mainly in the tropical and subtropical regions of South America. It constitutes one of the most important families of shrubs and secondary growth vegetation in Brazil. Many domesticated species have economic importance, such as tomato (Lycopersicum esculentum Mill.), potato (Solanum tuberosum L.), "jiló" (S. aethiopicum L.), "cubiu" (S. sessiliflorum Dunal), egg-plant (S. melongena L.). and tobacco (Nicotiana tabacum L.). Solanum L. is one of the most important genera of this family, being among the world's most numerous in species (with up to 1,200).

There are many articles about the Solanum genus pollen morphology, including the following: Salgado-
Labouriau et al. 1969; Sharma 1974; Anderson \& Gensel 1976; Symon 1981; Edmond 1984; Roubik \& Moreno 1991. These articles suggest a homogeneous morphological pattern to the pollen grains of this genus. Edmond (1984) emphasizes that there are not significant morphological variations in the pollen grains of Solanum species, though he admits to the existence of those variations. This autor also considers the pollen morphology of the Solanum nigrum to be the morphological pattern of this genus.

The aim of this work is to focus on the morphological description of the pollen of S. stramoniifolium, by starting its floral biology study as well as recording its different visitors. S. stramoniifolium characterizes itself by its bushy shape, being from 1 to $2 \mathrm{~m}$ high, usually armed with spines from 4 to $12 \mathrm{~mm}$ long; the stem is tomentose,

\footnotetext{
Instituto Nacional de Pesquisas da Amazônia, Av. André Araújo 2934, B. Petrópolis, C. Postal 478, CEP 69011-970, Manaus, AM, Brasil

2 Universidade Federal do Rio Grande do Sul

Universidade Federal de Uberlândia

4 Corresponding Author: alexbelha@hotmail.com
} 
with star-shaped, almost sessile hairs. The inflorescence of S. stramoniifolium is extra-axillar, simple, with 12 to 30 flowers (Ribeiro et al. 1999). The calyx is campanulate, more or less truncate, with hidden lobes; the corolla is white, usually with external purple hairs, lobulated near the base, and the lobes are ovolanceolate; anthers more or less conniving and slightly curved on the apex (Ribeiro et al. 1999). This species is heliophyte and in environments with diffuse light it is estiolate and with less branch development, in addition to a lower yield of flowers and fruits.

\section{Material and methods}

In the first phase, some samples of Solanum stramoniifolium Jacq. were collected for incorporation into INPA's Herbarium, Manaus - AM (Kinupp, V.F. \& Coletto-Silva, A. - collector n. 1831, voucher n. 208742). In the second phase, we carried out a palynological study of $S$. stramoniifolium with documentation and description of the pollen. The methodology used for recording the species of bees was by visitor count, photographic records and specimens collection with entomological nets. The observation of the visitors was carried out in the area of INPA's Campus in Manaus (Amazonas State), Comunidade Menino Deus do Curaçá in Boa Vista do Ramos (Amazonas State), Manacapuru and Itacoatiara (Amazonas State). These observations were made from October 2000 to April 2001. The averages of both maximum and minimum annual temperature in Manaus were $32.0-22.2^{\circ} \mathrm{C}$ and $31.9-23.4^{\circ} \mathrm{C}$, in 2000 and 2001, respectively. The annual average rainfall was $2599.6 \mathrm{~mm}$ in 2000 , and $2016.8 \mathrm{~mm}$ in 2001.

The pollen of $S$. stramoniifolium was collected from flower buds (fresh material) in INPA's Campus (Manaus) and treated by the standard method of acetolysis, following Erdtman (1960). From the acetolysed material slides were made for observation and documentation by light microscopy. For the measurement of the pollen grains as well as their morphological characterization, 25 randomly chosen grains from 5 different slides were measured. Arithmetic average and standard deviation were estimated for the morphometric data. The terminology adopted was based on Punt (1994).

\section{Results and discussion}

Observations of Visitors - Preliminary data (Fig. 1-3) show the presence of Melipona nebulosa (Camargo 1988), Trigona pallens (Fabricius 1793), Melipona seminigra merrillae (Cockerell 1920), Melipona compressipes manaosensis (Schwarz 1932) and one species of Eulaema (Apeulaema) cingulata (Fabricius 1804) collecting pollen from $S$. stramoniifolium. All the visitors, with the exception of the species Trigona pallens used the strategy of "buzz pollination" during the foraging behaviour. Published studies report that "buzz pollination syndrome" requires bees with a specific behaviour for pollen removal (Forni-Martins et al. 1998). Other studies provide evidences of the collection of pollen from Solanum species by bees, thus demonstrating the importance of this genus for the improvement of apiculture management (Absy et al. 1980; 1984).

Absy \& Kerr (1977) studying Melipona seminigra merrillae, and Marques-Souza et al. (1995) working with Melipona rufiventris paraensis (Ducke 1916) verified the collection of pollen by stingless bees in some species of the genus Solanum. Kerr et al. (1986; 1987) also verified pollen of S. апnиит (L) Morton, S. macrocarpon L. and S. melongena being collected by Melipona compressipes fasciculata
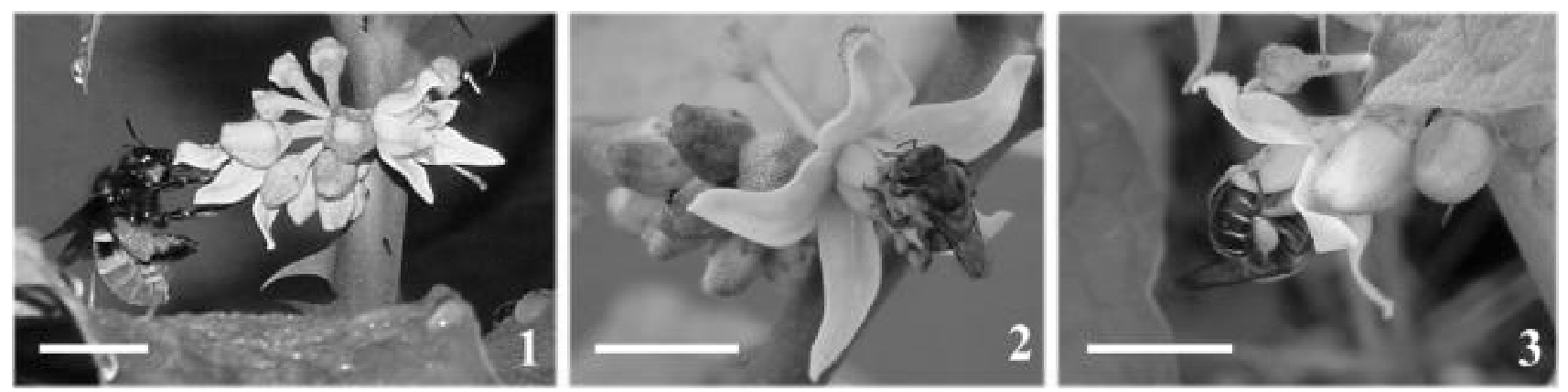

Figures 1-3. Some bees visiting Solanum stramoniifolium to collect pollen. 1. A stinging bee Eulaema (Apeulaema) cingulata. 2-3. Two species of stingless bees, Melipona seminigra merrillae and Melipona compressipes manaosensis, respectively. Scale bars $=2 \mathrm{~cm}(1)$, $1 \mathrm{~cm}(2-3)$. 
(popular name: "tíuba do Maranhão"). Marques-Souza et al. (1993) verified the collection of pollen from two species of the genus Solanum (Solanum myrianthum Britton ex Rusby and Solanum sp.) by Apis mellifera in the municipality of Ji-Paraná, RO, Brazil.

Palynological Data - The pollen of S. stramoniifolium (Fig. 4-6) is shown in the polar and equatorial positions. The morphometric data of the pollen grains referring to the values of the arithmetic averages of polar $(\mathrm{P})$ and equatorial (E) axis were: $34.8 \pm 1.6(27.5-42.5) \mu \mathrm{m}$ and $29.0 \pm 0.5(25-35) \mu \mathrm{m}$, respectively, being that the $\mathrm{P} / \mathrm{E}$ ratio was 1.22 . The morphological characteristics of the pollen grain of $S$. stramoniifolium are the following: small grain, subprolate shape, amb. circular, isopolar, monad; tricolporate; ectoaperture long $(19.3 \mu \mathrm{m})$ and narrow $(1.3 \mu \mathrm{m})$, endoaperture lalongate (width $=15.7 \mu \mathrm{m}$ and height $=3.7 \mu \mathrm{m}$ ), wide with round edges and fastigiate; the exine sculpture is psilate with sexine less thick than the exine and non evident columellae.

Edmond (1984) emphasizes that the pollen grains of the Solanum did no represent significant morphological variations, but admits the possibility of these variations among species of this genus. According to this author, the Solanum genus pollen grain morphological variations refer only to the opening type and exine ornamentation level. In the case of the last characteristic, it varies from little to completely not ornamented grains. The variations presented by Edmond (1984) are due to many factors, such as the homogeneity of the morphological characteristics, which reflects strong philogenetic relationships in the Solanum section, isolation mechanisms and speciation, and genomic intermediary combinations that can, on the whole, explain the similarities found in the morphological variations of the Solanum genus.

Roubik \& Moreno (1991) verified through of pollen morphological analyses of 11 species of Solanum from Barro Colorado Island (Panama Canal) that the pollen grains of the species are tricolporate and psilate. Other research that deals with the pollen morphology of the Solanum described it as having the psilate surface which was established through analyses of exine with optical microscopy in the studies of $S$. stramoniifolium.

Symon (1981) relates the small size of the pollen grain and the occurrence of the little complex ornamentation or lack of ornamentation in species of Solanum, with the expulsion process of these grains inside of the poricidal anthers. This process, according to the author, is generally executed through vibrations or "buzz pollination" by solitary bees. The same author also suggests that the large pollen grains with complex ornamentation could form deposits and block the anthers orifices in Solanum species. This way, a close relationship between the pollen morphology confirmed by acetolysis treatments and the pollination syndrome by "buzz pollination" presented in this research, reinforce the observations and the hypothesis of Symon (1981). Due to the fact that the pollen grains of S. stramoniifolium are small and with no ornamentation (psilate exine), it is probable that the grain will be expelled more easily from the poricidal anthers during the vibration of the bees.

Besides this, some authors (Erickson 1975; Thorp 1979; Corbert et al. 1982; Erickson \& Buchmann 1983) found that the presence of electrostatic forces, at the moment of pollination by vibration, could demonstrate an advantage promoting the attachment of the pollen
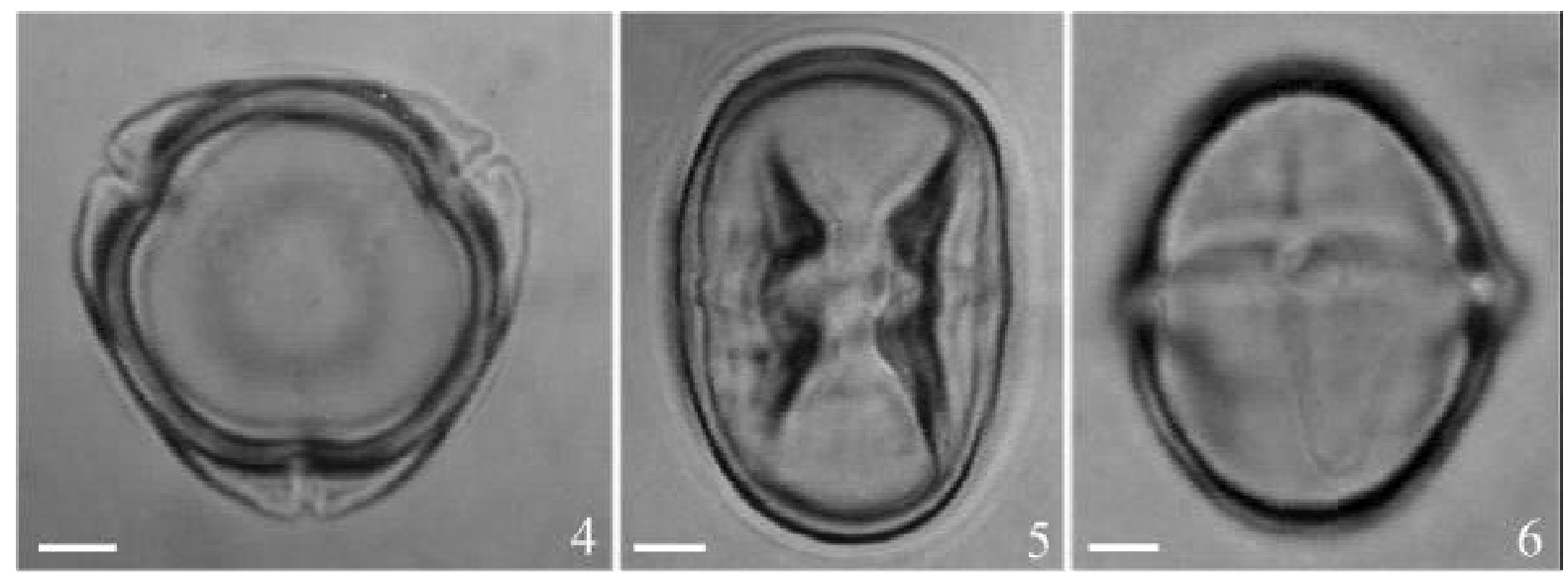

Figures 4-6. Pollen grains of Solanum stramoniifolium (Solanaceae). 4. Polar view. 5. Equatorial view showing two of the three colpi. 6. Equatorial view showing the surface of the exine. Scale bars $=5 \mu \mathrm{m}$. 
to the body of the insect, which facilitates its transference to the stigma.

An important fact that should be reinforced is that there is a cost-benefit relationship involved in the pollination syndrome by vibrations of the bees. The bees exert a large amount of energy to move their flight muscles and to complete the vibration process. Also, there is a certain degree of waste of pollen grains in this process, and only pollen with a high protein level could justify this plant-insect relationship. This high protein level was encountered in the research of Buchmann (1986).

Carvalho et al. (2001) observed 14 species of bees of the Andrenidae, Apidae and Halictidae families which were visiting the inflorescence of Solanum palinacanthum Dunal, in Cruz das Almas, Bahia. These authors considered Bombus (Fervidobombus) atratus Franklin, Bombus (Fervidobombus) morio Swederus and Eulaema nigrita Lepeletier as the principal pollinators based on the pollen load and visiting time per flower. The bee's collection activity peak was observed to be between 9:00 a.m. and 3:00 p.m. It was also observed that the bees utilized the same time period for collecting pollen in S. stramoniifolium.

In conclusion we have found that S. stramoniifolium may be used as an apiculture resource for different stinging and stingless bee species providing pollen as a reward throughout the year; Eulaema (Apeulaema) cingulata, Melipona nebulosa, Trigona pallens, Melipona seminigra merrillae and Melipona compressipes manaosensis visit $S$. stramoniifolim to collect pollen; the S. stramoniifolium pollen morphology seems to resemble the Solanum genus morphological pattern studied by some authors. The reduced size of the grain and the psilated aspect of the exine justifies the type of pollinization syndrome by vibration found in the majority of the observed bees; "buzz pollination" is not the only foraging strategy observed for $S$. stramoniifolium, since "pillage" of the anthers is a behavioral form, which allows grain access by small bees as observed with Trigona pallens; complementary studies on the floral biology of S. stramoniifolium should be intensified in the Amazon region for a better understanding of the existing relationships between the pollinators and this species.

\section{Acknowledgments}

The authors express their thanks to Prof. Dr. Francisco de Assis Ribeiro dos Santos and to Cláudio
Cruz da Silva, of the Plant Micromorfology Laboratory of Universidade Federal de Feira de Santana, for their invaluable help on the confirmation of the pollen description; to Prof. Dr. João Maria Franco de Camargo, for the identification of the stingless bee species visiting $S$. stramoniifolium; to Prof. Dr. Márcio Luis de Oliveira, for the identification of the Eulaema apeulaema cingulata; to Prof. Dr. Michael J.G. Hopkins and Ana Cláudia Lessa, for their help on the English language composition corrections; to Cleonice de Oliveira Moura, do Laboratório de Palinologia do Instituto Nacional de Pesquisas da Amazônia, for the suggestions; to MCT/INPA, for the scholarship granted to the first author by the Institutional Capacity Programe (ICP).

\section{References}

Absy, M.L. \& Kerr, W.E. 1977. Algumas plantas visitadas para obtenção de pólen por operárias de Melipona seminigra merrillae em Manaus. Acta Amazonica 7(3): 309-315.

Absy, M.L.; Bezerra, E.B. \& Kerr, W.E. 1980. Plantas nectaríferas utilizadas por duas espécies de Melipona da Amazônia. Acta Amazonica 10(2): 271-281.

Absy, M.L.; Camargo, J.M.F.; Kerr, W.E. \& Miranda, I.P.A. 1984. Espécies de plantas visitadas por Meliponinae (Hymenoptera; Apoidea), para coleta de pólen na região do médio Amazonas. Revista Brasileira de Biologia 44(2): 227-237.

Anderson, G.J. \& Gensel, P.G. 1976. Pollen morphology and the systematics of Solanum Section. Basarthrum. Pollen et Spores 18: 533-552.

Buchmann, S.L. 1986. Vibratile pollination in Solanum and Lycopersicon: a look at pollen chemistry. Pp. 218-252. In: W.G. D’Arcy (ed.). Solanaceae: biology and systematics. Columbia University Press, New York.

Carvalho, C.A.L.; Marques, O.M.; Vidal, C.A. \& Neves, A.M.S. 2001. Foraging behavior of bees (Hymenoptera, Apoidea) in flowers of Solanum palinacanthum Dunal (Solanaceae). Revista Brasileira de Zoociências 3(1): 35-44.

Corbert, S.A.; Beament, J.W.L. \& Eisikowitch, D. 1982. Are eletrostatic forces involved in pollen transfer? Plant Cell Environment 5: 125-129.

Edmonds, J.M. 1984. Pollen morphology of Solanum L. section Solanum. Botanical Journal of the Linnean Society 88: 237-251.

Erdtman, G. 1960. The acetolysis method in a revised description. Svensk Botanisk Tidskrift, Lund 54(4): 561-564.

Erickson, E.H. 1975. Surface electric potentials on worker honeybees leaving and entering the hive. Journal of Apicultural Research 14: 141-147. 
Erickson, E.H. \& Buchmann, S.L. 1983. Electrostatics and pollination. Pp. 173-184. In: C.E. Jones \& R.J. Little (eds.). Handbook of experimental pollination biology. Scientific and Academic Editions, New York.

Forni-Martins, E.R.; Marques, M.C.M. \& Lemes, M.R. 1998. Biologia Floral e Reprodução de Solanum paniculatum L. (Solanaceae) no Estado de São Paulo, Brasil. Revista Brasileira de Botânica 21(2): 117-124.

Kerr, W.E.; Absy, M.L. \& Marques-Souza, A.C. 1986/1987. Espécies nectaríferas e poliníferas utilizadas pela abelha Melipona compressipes fasciculata (Meliponinae, Apidae), no Maranhão. Acta Amazonica 16/17: 145-155.

Marques-Souza, A.C.; Absy, M.L.; Condé, P.A.A. \& Coelho, H.A. 1993. Dados da obtenção do pólen por operárias de Apis mellifera no município de Ji-Paraná (RO), Brasil. Acta Amazonica 23(1): 59-76.

Marques-Souza, A.C.; Absy, M.L.; Kerr, W.E. \& Peralta, F.J.A. 1995. Pólen coletado por duas espécies de meliponínios (Hymenoptera, Apidae) da Amazônia. Revista Brasileira de Biologia 55(4): 855-864.

Peter, K.E. 1994. Special differentiations associated with pollinator attraction. Pp. 148-189. In: Diversity and Evolutionary Biology of Tropical Flowers. Cambridge Tropical Biology Series.

Punt, W.; Blackmore, S. \& Le Thomas, A. 1994. Glossary of Pollen and Spores Terminology. Utrecht, LPP Foundation.
Ribeiro, J.E.L.S.; Hopkins, M.J.G.; Vicentini, A.; Sothers, C.A.; Costa, M.A.S.; Brito, J.M.; Souza, M.A.D.; Martins, L.H.P.; Lohmann, L.G.; Assunção, P.A.C.L.; Pereira, E.C.; Silva, C.F.; Mesquita, M.R. \& Procópio, L. 1999. Flora da Reserva Ducke: Guia de Identificação das Plantas Vasculares de uma Floresta de Terra Firme na Amazônia Central. INPA, Manaus.

Roubik, D.W. \& Moreno, J.E.P. 1991. Pollen and spores of Barro Colorado Island. Monographs in Systematic Botany From The Missouri Botanical Garden 36: 146.

Salgado-Labouriau, M.L.; Freire de Carvalho, L.D.A. \& Cavalcante, P. 1969. Pollen grains of Plants of the Cerrado XXI - Ebenaceae, Nyctaginaceae, Phamnaceae and Solanaceae. Boletim do Museu Paraense Emílio Goeldi, nova Série, Botânica 32: 1-12.

Sharma, B.D. 1974. Contributions to the palynotaxonomy of the genus Solanum Linn. Journal of Palynology 10: 51-68.

Symon, D.E. 1981. A revision of the genus Solanum L. in Australia. Journal of the Adelaide Botanic Gardens 4: 1-367.

Thorp, R.W. 1979. Structural, behavioral, and physiological adaptations of bees (Apoidea) for collecting pollen. Annals of the Missouri Botanical Garden 66: 788-812. 